\title{
Geothermal Energy Utilization in Jordanian Deserts
}

\author{
Sanaa Al-Zyoud \\ Department of Applied Earth and Environmental Sciences, Institute of Earth and Environmental Sciences, Al Al-Bayt University, \\ Al Mafraq, Jordan \\ Email: alzyoud@aabu.edu.jo
}

How to cite this paper: Al-Zyoud, S. (2019) Geothermal Energy Utilization in Jordanian Deserts. International Journal of Geosciences, 10, 906-918.

https://doi.org/10.4236/ijg.2019.1010051

Received: August 25, 2019

Accepted: October 18, 2019

Published: October 21, 2019

Copyright $\odot 2019$ by author(s) and Scientific Research Publishing Inc. This work is licensed under the Creative Commons Attribution International License (CC BY 4.0).

http://creativecommons.org/licenses/by/4.0/

\begin{abstract}
Jordan is blessed with shallow geothermal resources in NE and SE deserts. Jordanian deserts compose more than $70 \%$ of the country area. Furthermore, it's the second vital area in fauna and flora variation after Jordan valley. Geothermal gradient in this area shows high promising future potential. New renewable energy systems installation in Jordan will have a positive environmental and economic contribution to the national bill. Currently, limited geothermal utilizations were evaluated in the Jordanian deserts. Thermal waters in the deserts were used for irrigation only. Six different applications for direct and indirect geothermal applications in Jordanian deserts were suggested and evaluated. Ground source heat pumps for heating and cooling purposes and crops drying were expected to be the most appropriate applications of geothermal energy in the deserts. Geothermal utilizations were investigated regarding their probable impact on local and national economic scale. Therefore, an integrated plan for geothermal applications in Jordan is becoming very essential in the future. It has been found that geothermal energy in Jordanian deserts could be utilized for different applications. Despite of the potential political, technical and financial barriers, exploiting new geothermal utilization in the deserts will contribute to solving socio-economic and environmental problems challenging poor deserts areas.
\end{abstract}

\section{Keywords}

Geothermal Shallow Systems, Direct and Indirect Utilization, Deserts, Jordan

\section{Introduction}

Jordan, as one of the Middle East developing countries, has continuous environmental and economic concerns about energy resources. In the last three years, 
a total growth in electric consumption was reached 10\%. About 2429 Million JD were paid to cover the costs of 17,574 GWh of electricity consumption in 2017 [1]. Therefore, the needs for exploiting new renewable energy resources extremely expanded. Currently, 6\% of total energy production is covered by renewable energy in Jordan; it's expected to reach up to $30 \%$ by 2025 . More than $23 \%$ of energy was consumed by residential areas with a demand growth of $8 \%$ in the last two years. About $65 \%$ of this consumption is used for heating and cooling [2]. It's reported that $92 \%$ of the current electricity supply is met by conventional fossil fuel resources. Therefore, the necessity of integrating new, clean and renewable energy resources in Jordan had increased. Extensive investigations have been implemented for renewable energy utilization in Jordan. Solar, wind, biomass and geothermal energy resources are recently exploited in the country. Renewable energy systems installation in Jordan will have a positive influence on $\mathrm{CO}_{2}$ reduction. In addition, this will reduce the national energy bill, too.

Jordan is enriched with shallow geothermal resources scattered all around the country. Geothermal fields are characterized by enormous hot springs and thermal wells, as well. Most of the low enthalpy geothermal resources are located along Dead Sea Fault Zone. Dead Sea Fault tectonic activities are responsible for most geothermal gradient anomalies in the country. Natural Resources Authority (NRA) was one of the early authorities which conducted different geothermal explorations in Jordan. Geothermal energy in Jordan has received different investigations from 1965 to present [3]-[8]. In the last three decades, geothermal energy resources were evaluated for their future utilization. Shallow geothermal resources were investigated into their heating and cooling applications. In addition, prospective geothermal fields, in some high geothermal gradient areas, were evaluated for their utilization in power generation [9] [10] [11]. Geothermal gradient map for Jordan shows that geothermal gradient averages $3.3^{\circ} \mathrm{C} / 100 \mathrm{~m}$. Four geothermal fields were outlined for further evaluation. Geothermal gradient in these fields exceeds the average geothermal gradient in Jordan [12]. Thermal water is discharged (or extracted) from Upper Cretaceous Limestone in northern Jordan, while it is circulated upward from Lower Cretaceous Sandstone in middle to southern Jordan. The largest field extends in western Jordan along Dead Sea Fault. The rest three fields are located in the Jordan desert. Jordan desert shows a promising geothermal potential for different applications. [13] stated that the first $100 \mathrm{~m}$ in subsurface would be suitable for heat and cool storage in various locations in Jordan. It has been found that subsurface temperature in NE Jordan desert averages $19^{\circ} \mathrm{C}[10]$.

International Geothermal Association (IGA) outlined that Jordan installed capacity for geothermal energy is about 153.3 MWh. It's stated that the potential geothermal energy is $1540 \mathrm{TJ} / \mathrm{yr}$, too. Consequently, the overall geothermal energy utilization capacity factor does not exceed 0.42 in Jordan currently [14] [15]. Jordan government played an obvious role in geothermal energy installation. It should promote the needed policy and legislation to facilitate the investment. In 
addition, the current research status and projects for further potential exploration have to be supported by the government. Updated investigation should be provided to the public sector highlighting the geothermal potential and its applications in the country. On the other hand, several geothermal applications were only discussed for the western Dead Sea Fault Geothermal Field. Limited applications were investigated from one prospect in one selected study area in western Jordan. Limited geothermal utilizations were discussed in some geothermal fields in Jordan. Jordanian deserts which enriched with shallow geothermal systems don't use such sources widely. In addition, deserts population facing difficult challenges in terms of energy supply, geothermal energy would satisfy their needs effectively. Therefore, an integrated plan for geothermal applications in Jordanian deserts is becoming very essential in near future.

In the present work, prospective geothermal resources in Jordanian desert are outlined. Geothermal energy potential with regards of optimum future utilization will be discussed. Thus, a comprehensive prospect strategy for exploiting geothermal resources in the deserts will be suggested.

\section{Current Geothermal Energy Utilization in the Jordan Desert}

Geothermal energy systems are divided into deep and shallow systems. Both geothermal systems have direct and indirect use. Power production, in which energy usage comes from 3000 to $5000 \mathrm{~m}$ depth, is one of the direct applications for deep geothermal energy utilization. This depth could be few hundreds of meters in high geothermal gradient areas. Some other countries derive more than 10 percent of their electricity from geothermal sources (i.e. El Salvador, New Zealand and the Philippines). Worldwide, 67,000 GWh of electricity is estimated to be generated from the total $10,700 \mathrm{MW}$ installed geothermal power capacity [16]. Other applications for deep and shallow geothermal systems are heating and cooling. Usually, space or district heating utilization comes from depth 400 to $3000 \mathrm{~m}$ or directly from some discharged hot water (i.e. thermal springs). Shallow geothermal system is utilizing energy from depths up to $400 \mathrm{~m}$. This system use earth subsurface directly as energy capacity storage for both heating and cooling. Ground source heat pumps are the main form of utilizing for this energy type. It's one of the common examples of the indirect use of shallow geothermal resources composing $68 \%$ from the total usage [17]. Shallow geothermal systems have various indirect applications such as fish farming, green house heating and swimming pools. Currently, about 73 countries around the world make direct use of a total geothermal energy output of 75.9 terawatt hours (TWh) per year. The number of countries using direct applications of geothermal energy is increasing steadily [16] [18].

In Jordan, shallow geothermal systems are abundant. Up to date no deep geothermal system had been installed, yet. Recently, geothermal energy applications feasibility in Jordan has been evaluated for possible applications such as power generation, heating and cooling purposes [19] [20] [21]. [9] concluded that the 
electric power generation could be achieved in Jordan. This can be utilized through geothermal binary power plants at hot springs. He recommended further feasibility evaluations to be implemented. [10] and [11] were investigated NE basaltic (in the deserts) reservoir for cooling purposes. They developed a numerical 3D model to predict the future performance of the geothermal cooling reservoir. Their studies show high feasibility (hydraulically and thermally) of geothermal utilization for cooling purposes. They developed a robust and flexible model which can be extended for analyzing other potential sites. Ground heat source exchanger was designed by [22] utilizes geothermal energy in heating in Mai'n. In addition, he investigated the feasibility of designing a ground heat exchanger system to pump geothermal energy under the weather conditions in this area. He found that geo-exchange systems will save around $70 \%$ in the heating mode, and up to $50 \%$ in the cooling mode compared to conventional fossil fuel systems. In addition, [21] compared the efficiency ground source heat pump/closed loop geothermal system with oil shale resources in northern Jordan. They calculated the savings in fuel oil to be about 9.35 Million barrels when using the geothermal system. They found that the reduction of $\mathrm{CO}_{2}$ emissions will be 1.5 Million $\mathrm{m}^{3}$. They concluded that geothermal heat pumps are better for satisfying cooling and heating requirements in the study area. [13] found that standing column well systems are suitable in geological regions with plentiful groundwater. They also compared standing column well with ground source heat pumps (closed and open). They included Amman, Aqaba, Ghor-Safi, Irbid, Ma'an, Shoubak, and Zarqa in their investigation. They concluded that standing column well suit many geothermal places in Jordan. It has been found that cooling and heating using geothermal heat exchangers in central Jordan will lead to about $15 \%-30 \%$ savings in energy consumption [23]. Recently, ground source heat pumps and exchanger applications became a promising environmental geothermal application in Jordan.

Currently, geothermal energy has been used for indirect and direct utilization very rarely. Thermal water in West Jordan is currently utilized as curative water for its therapeutic value. The high mineralization as well as high temperature is recommended for several types of treatments. For example, Afra and Burbeitta thermal water is good for Degenerative Disc and Post Traumatic problems treatments [17] [22]. Thermal springs, which extend along Dead Sea fault from northern Jordan till the eastern coasts of Dead Sea, were all utilized for medical care, only. Different spa and resorts were constructed nearby most thermal springs in this area. In addition, some thermal water is currently used for irrigation. Farmers in this area found that water mineralization is very efficient for their crops. Water mineralization provides unique cations/anions nutrients needed by most crops. They cool the water in nearby pools and use it directly for crops irrigation. In NE Jordan desert, this application is adopted, too. Other modest fish farms were found in Azraq area (Jordan oasis in NE desert). Indirect shallow geothermal energy has been utilized for heating and cooling other areas in Jordan. Ground source heat pumps (closed loops) had been installed in selected 
public infrastructure (i.e. The American University of Madaba, The National Center for Research and Development building at the Higher Council of Science and Technology in Amman). Other usages of this water are domestic applications. Such water is currently utilized for bathing, washing and other laundry applications at home. Other direct and indirect utilizations are not applied widely in Jordan. This is because of the lack of experts and the limited financial resources. Undeveloped governmental legislations play an important role in reducing geothermal energy utilization in the country.

\section{Prospective Geothermal Energy Utilization in the Jordan Desert}

Two third of Jordan area is of arid to semi-arid climate. Thus, deserts cover more than $66,000 \mathrm{Km}^{2}$ from the total area of the country. As the desert is exposed to daily and seasonally temperature variations, the differences in constructions' heating and cooling loads in deserts became very challenging. Jordan desert is characterized by a very cold winter and a very hot summer. Therefore, this area needs for heating and cooling is relatively high in comparison to other areas in Jordan. On the other hand, it has been found that Jordan deserts have various types of soil. It's the second important area in regards to fauna and flora variation after Jordan valley. Therefore, it is one of the most important agricultural fields on the national scale.

Jordan deserts have three distinctive geothermal fields. [12] discussed all potential geothermal fields in Jordan. High geothermal gradient field exists in $\mathrm{Ar}$ Risha gas field nearby Jordan-Iraq borders. This field would have great geothermal potential for power generation in remote areas. Other shallow geothermal fields are found at $\mathrm{Al}$ Kahlidiyya nearby Azraq Oasis and in SE desert at Al Jufr [24] [25] [26].

Thermal water (springs and wells) temperature ranges between $20^{\circ} \mathrm{C}$ and $68.50^{\circ} \mathrm{C}$ in Jordan [7] [8] [12]. According to water temperature, geothermal energy resources can be classified into three types: 1) temperature geothermal resource of temperature less than $\left.90^{\circ} \mathrm{C}, 2\right)$ moderate temperature geothermal resource ranges from $90^{\circ} \mathrm{C}$ to $150^{\circ} \mathrm{C}$ and 3) high temperature geothermal resource (greater than $150^{\circ} \mathrm{C}$ ). Commonly, the high temperature geothermal group is used for electric power generation [27]. According to the geothermal field's locations, geothermal gradients and local residence requirements, geothermal energy direct and indirect utilization in the Jordan deserts could be discussed as follow:

\section{1) Power generation}

Jordan consumed about 18,000 GWh of electric power in 2017 with an increase of about $5 \%$ than in 2016 . About $60 \%$ of the total electric consumption comes from the residential sector and water pumping [1]. Generally, water sector consumes about $15 \%$ of total electric power consumption in Jordan. More than $40 \%$ of total 3272 groundwater wells in Jordan are drilled in deserts. In 2017 the total groundwater abstraction was reached 229 MCM, more than 35\% of this amount is used for irrigation. In the last 4 years, the water demand in- 
creased by $40 \%$ due to Syrian refugees' flux [28]. Despite of that, Jordan desert (NE and SE) has low population density in comparable with the main cities (i.e. Amman, Zarqa and Irbid), it's comprising $14 \%$ from the total population of 10.309.000 in 2018 [29]. Therefore, it's expected that the residential electric consumption in the desert will not exceed $6 \%$ of the total electric consumption in the country. Consequently, NE and SE deserts in Jordan need electric power for water pumping. Being remote accessed areas from the public grid suppliers approve their needs for local electric power generation. Ar Risha geothermal field shows a potential for power generation. It has been found an important evidence on high geothermal gradient in this region. As this field exists about $300 \mathrm{~km}$ east to Amman, it is considered a significant opportunity for remote areas electric power production. Around $15,000 \mathrm{~km}^{2}$ could be covered in NE Jordan for its electric power consumption.

Since the geothermal gradient for this field is ranging between medium to high, the prospect of electrical power geothermal-based generation through geothermal binary electrical power plant is suggested to be evaluated. Therefore, further feasibility evaluation is highly recommended, for prospect utilization, to be implemented in Ar Risha geothermal field. For a comparative case in Jordan, [9] suggested that the electric power generation could be achieved in Dead Sea Fault geothermal field through the utilization of geothermal binary power plants in the hot springs with a temperature more than $80^{\circ} \mathrm{C}$. The other geothermal fields in Al Khalidiyya and SE desert did not show good potential for power generation due to low local geothermal gradient exhibited [12].

\section{2) Ground source heat pumps for heating and cooling purposes}

Deserts demonstrate daily and seasonal temperature variations very obviously. The yearly heating and cooling loads in these areas range between 0.04 and 0.14 MW [10] [30]. The possibility of utilizing geothermal energy for heating and cooling in the desert comes from the fact that at 20 to $100 \mathrm{~m}$ depth a steady subsurface temperature is recorded. This suggests various applications of geothermal energy despite of air temperature variations [13] [31]. This depth is suitable for being a heat storage or exchanger in summer and winter, as well as, in day and night. Subsurface acts as heat source when air temperature decreases and heat sink when air temperature increases. In winter, the heat will be extracted from the ground, increasing the heat pump temperature then used for heating systems in low temperature records. The system will be reversed in summer; the heat from infrastructure will be rejected into the subsurface in order to be cooled. Thus, heat pumps are connecting the underground and permits the heat exchange from/to the ground in subsurface. Ground source heat pumps are widely used in the last decades, they became common for both residential and commercial cooling and heating applications worldwide. In the desert, where the temperature variation exists, such systems can provide a significant share in reducing electric consumption. Ground source heat pump systems could be used in Jordan for both open-loop and closed-loop. Open loop Ground source heat pump systems will use the pump to circulate thermal water through the heat 
pump exchanger for heating purposes. Cooling utilization needs cold groundwater. For irrigation purposes, groundwater is rarely available according over exploitation in NE Jordan deserts. Open loop ground source heat pumps for cooling purpose can be utilized more in SE desert. Despite that, [10] [11] had investigated open loop system in NE Jordan for cooling purposes. They revealed a moderate to high potential in this area. In Jordan, the preferable ground source heat pump system is a closed loop which employs a pump to circulate fluid through buried pipes. Such pipes are installed vertically or horizontally. The third type is standing column well, which is a combination of the closed and the open loops. This system has been used in Jordan [32]; it can be used in the desert, too. Again, due to the wide seasonal temperature variations and steady underground temperature $\left(19^{\circ} \mathrm{C}-22^{\circ} \mathrm{C}\right)$, the closed loop system, will be highly recommended for heating and cooling in the deserts. Open loop ground source heat pumps (or standing column well) can be applied for heating and cooling under certain circumstances. It has been found that geothermal heating and cooling will reduce electric consumption by about $60 \%$ in this area. On the other hand, space heating in deserts is also requested for certain crops cultures. Some crops need a specific heating consideration; i.e. mushroom culture required temperature ranges between $38^{\circ} \mathrm{C}$ to $70^{\circ} \mathrm{C}$ [14]. This temperature can be satisfied very usefully with the available shallow geothermal resources in the desert. Mushroom would be considered as a new and healthy source of food in this area, available yearlong at an affordable price with using geothermal resources in the desert. Consequently, the three geothermal fields in the desert could be utilized for heating purposes. Furthermore, Jordan desert infrastructures could be cooled by geothermal closed loop ground source heat exchanger.

\section{3) Greenhouse heating}

Deserts are the second agricultural production area in Jordan. Soil types' variation, area availability, as well as, water accessibility in this region lead to become very promising for agriculture. Installing greenhouses in this region will expand the crops production (i.e. tomato, pepper, cucumber, roses, carrots, paprika, lettuce, green beans, strawberries and certain herbs). Therefore, geothermal greenhouses could produce a range of high-quality products in all seasons.

Normally, winter nights came extremely cold where freezing temperatures destroy most of the crops. Being close to low enthalpy geothermal reservoir gives farmers a chance to protect their crops in a proper way. Recently, greenhouse heating became the most common application of thermal waters worldwide. Using geothermal energy for greenhouse heating is less expensive than other energy resources. Additionally, geothermal heating systems are relatively simple to install, maintain and improve food production efficiency by using the available resource [33]. In addition, geothermal heating eliminates fungal infection by reducing the humidity in greenhouse; this will lead to a decrease in the production costs.

According to [15] greenhouses can be heated either by plastic tubes lies along the greenhouse wall to exchange heat with air or circulating warm water in soil 
subsurface or using hot water with wall fans to spread heat. Therefore, natural or forced air movement will be used. Thermal water temperatures between $40^{\circ} \mathrm{C}$ to $100^{\circ} \mathrm{C}$, is suitable for this application depending on the required temperature within the greenhouse [33].

On the other hand, a very useful application for geothermal energy is greenhouse integration with desalination of brackish water. NE desert has a serious overexploitation of groundwater which resulted in the water to be more saline. Consequently, it will be adequate to use geothermal resources in this area for both greenhouses and brackish water desalination. [34] suggested that geothermal energy would be used for heating the brackish water while the resulting hot vapor will be used to warm the greenhouse.

\section{4) Aquaculture}

Aquaculture pond heating is among the most common applications of geothermal energy in Europe. As the temperature drops in winter and at night in the desert, such aquaculture will just be possible seasonally. The integration of geothermal energy in aquaculture will extend the availability of products for the whole year. Low enthalpy geothermal resources in the Jordan desert (Al Khalidiyya and SE desert geothermal fields) could be utilized (at night and winter) for aquaculture purposes. It's stated that the available temperature at the mentioned fields would be very suitable for fish farming. In general aquaculture can be applied in the temperature ranges $\left(20^{\circ} \mathrm{C}\right.$ to $\left.30^{\circ} \mathrm{C}\right)$ [17]. This will give a new chance for new exported fish with good quality in SE desert nearby Aqaba portal. In addition, at NE desert, fish farming will satisfy the needs for local market demand as it is not far from main cities. Thus, fish farming in water heated with geothermal energy makes production available, cheap and profitable to the country. According to [35], many species could be cultivated; carp, catfish, tilapia, frogs, mullet, eels, salmon, sturgeon, shrimps, lobsters, crayfish, crabs, oysters, clams, scallops, alligators, mussels and abalone. Nevertheless, thermal, as well as ground, waters must be evaluated and adjusted to be in suitable quality for fish farming.

\section{5) Crops drying}

This application will present Jordan agricultural products for the international markets. Using dried crops will exceed the product life with the same excellent quality. Thus, this will lead to share part in increasing the national income. The excess amounts of crops that are currently produced in Jordan are dropping the prices at local market for less than the capital expenses. Large quantities were disposed in a non-environmentally way. In addition, lots of women are looking for future financial empowerment. Decreasing, unemployment is among the most important national targets in 2019. Consequently, crops drying will contribute to solve socio-economic and environmental problems challenging poor areas in the desert. Additionally, this will preserve a growing range of products and increase the chances of agricultural industries in the desert.

Using the available geothermal resources for food drying in Jordan will be the second-best option in the country. Solar energy is considered the main one. Geo- 
thermal resources could give higher continuity of drying process at nights or in winter. Such an integrated (solar-geothermal) food drying systems around the geothermal fields in Jordan will be the best option. Geothermal energy in winter and sun absent will do what solar can do in summer and sunshine. Integrated geothermal heat exchanger with photovoltaic cell will give the maximum operation of food drying for 24 hours. The air is heated by solar energy (daytime) the thermal water (nighttime) then will be blown into the drying chamber for the drying process. The available geothermal gradient in the Jordan desert at shallow geothermal fields will supply this system with the needed temperature. [14] stated that food drying needs $60^{\circ} \mathrm{C}$ to $90^{\circ} \mathrm{C}$ for best results. This is dependent on the crop type and temperature availability. Different crops could be dried in the Jordan deserts as they are already planted their (i.e. dates, tomatoes, potato, grapes, apricots and goiter). Excess amounts of fruit products which planted in the deserts like apricots and grapes could be dried, too. Another product could be involved in this process; yogurt, as this area is producing all dairy products. The desert is enriched with wide variety of herbs; such products will be characterized by high prices, light weights with excellent quality for exporting after dried. Shallow geothermal fields in Jordan desert show promising future utilization in the dried food industry.

\section{6) Spa and resorts for bathing and swimming}

Jordan desert is enriched with historical castles and palaces. Several ancient civilizations settled and build their homes there. From a touristic point of view, integration of the regions' heritage with new modern resorts will be a brilliant future investment of the desert resources in Jordan. Thermal water was found to have such a high mineralization percentage. This hot water can easily be exploited as curative water. Different disorders could be treated while enjoying the ancient history and being a part of it. For touristic, medical, historical and social aspects constructing thermal spas in $\mathrm{Al} \mathrm{Khalidiyya} \mathrm{geothermal} \mathrm{field} \mathrm{will} \mathrm{be} \mathrm{very}$ attractive in the future. In the southern desert, this will have the same importance especially if the thermal waters could be transported to Wadi Rum or Petra to satisfy the same vision in that area.

\section{Challenges and Barriers for Geothermal Energy Utilization in Jordan Deserts}

Governmental legislation and promotion policy for geothermal resources in Jordan are inadequate for attracting national or international investments in geothermal projects. The government should be an effective partner for initiating future geothermal projects. In addition, early geothermal phases of exploration could be implemented by the government in this regard. Further development of geothermal systems needs a right institutional coordinated framework with consultation among all public and private partners. Government and investors must develop models which can deliver services with updated technologies to the community in a reasonable price parallel with ongoing industry sus- 
tainability. In addition to that, technical expertise is a highly crucial requirement for geothermal development achievement. Nevertheless, Jordan lacks the qualified geothermal experts. On the other hand, one of the most financial barriers facing geothermal installation is high cost technologies. The initiation costs of geothermal projects such as energy resource assessments or feasibility studies should be covered by the public sector to encourage private investors. However, in Jordan, the governmental fund availability for this area is very limited. Commonly, geothermal energy research in Jordan is served by external funding resource. The integration of all national efforts will lead to best utilization of geothermal resources in Jordanian deserts.

\section{Conclusion}

Jordanian deserts show high potential for geothermal energy, but they were not evaluated for their future utilizations. Deserts' special distribution provides a promising future opportunity for such applications. Jordanian deserts resources could play an effective role in the country's future. Jordan deserts represent one of the most important agricultural fields on the national scale. Updated investigation should be delivered to the public and private sectors highlighting the geothermal potential in this area and its applications. The importance of this work comes to integrate geothermal applications in one suggested comprehensive plan. According to the geothermal field's locations, geothermal gradients and local residence requirements; geothermal energy direct and indirect utilization in the Jordan deserts were evaluated. It has been suggested that power production could be utilized from Ar Risha geothermal field. The other two shallow geothermal fields; Al-Khalidiyya and SE desert could be utilized for other direct applications. Seasonal temperature variations stress heating and cooling systems requirements in the desert. Ground source heat pumps will be very suitable especially with the steady subsurface temperature in the desert. Greenhouse heating at cold winter nights will protect the crops from freezing. In addition, depending on the crop type and temperature availability, different crops could be dried in the Jordan deserts for long and excellent preservation. Furthermore, fish farming will give a chance for new exported good fish quality and satisfy the local market's needs. Finally, different disorders could be treated on future designed spa while enjoying the ancient history and being a part of it in the desert. An integrated plan for geothermal applications in Jordan is becoming very essential in the near future for energy policies and strategies. Geothermal resources utilization in the desert leads to having a positive environmental and economic contribution to the national bill. Despite of the political, technical and financial barriers that may be faced, exploiting new geothermal utilization in the deserts will contribute to solving socio-economic and environmental problems challenging poor deserts areas.

\section{Conflicts of Interest}

The author declares no conflicts of interest regarding the publication of this paper. 


\section{References}

[1] MEMR (Ministry of Energy and Mineral Resources) (2017) Annual Report 2017. https://www.memr.gov.jo/echobusv3.0/SystemAssets/469adf39-0f2f-4d01-a72b-d39 4c3b56332.pdf

[2] MEMR (Ministry of Energy and Mineral Resources) (2019) Energy 2019 Facts and Figures Brochure.

https://www.memr.gov.jo/EchoBusV3.0/SystemAssets/PDFs/EN/BroshorEn2019.pdf

[3] MacDonald, M. and Partners (1965) East Bank Jordan Water Resources. Report to Central Water Authority, Hashemite Kingdom of Jordan.

[4] Bender, F. (1974) Geology of Jordan. Contribution of the Regional Geology of the Earth. Gebruder Borntraeger, Berlin.

[5] Abu-Ajamieh, M. (1980) The Geothermal Resources of Zarqa Ma'en and Zara, NRA, Amman.

[6] Sunna, B. and Jordan Aqua Conservation Association (JACA) (2004) Recommended Approaches to Develop the Direct Utilization of the Geothermal Energy (Hot Water) in Jordan. International Water Demand Management Conference, Jordan.

[7] Swarieh, A. (2000) Geothermal Energy Resources in Jordan, Country Update Report. Proceedings of the World Geothermal Congress, Kyushu-Tohoku, Japan.

[8] Schäffer, R. and Sass, I. (2014) The Thermal Springs of Jordan. Environmental Earth Sciences, 72, 171-187. https://doi.org/10.1007/s12665-013-2944-4

[9] Abu-Hamatteh, Z., Al-Zughoul, K. and Al-Jufout, S. (2011) Potential Geothermal Energy Utilization in Jordan: Possible Electrical Power Generation. International Journal of Thermal and Environmental Engineering, 3, 9-14.

[10] Al-Zyoud, S. (2012) Geothermal Cooling in Arid Regions: An Investigation of the Jordan Harrat Aquifer System. Doctoral Dissertation, Technische Universität Darmstadt, $122 \mathrm{p}$.

[11] Al-Zyoud, S., Rühaak, W. and Sass, I. (2014) Dynamic Numerical Modeling of the Usage of Groundwater for Cooling in North East Jordan-A Geothermal Case Study. Renewable Energy, 62, 63-72. https://doi.org/10.1016/j.renene.2013.06.027

[12] Al-Zyoud, S. (2019) Geothermal Energy Resources for Shallow Enthalpy Utilization in Jordan.

[13] Al-Sarkhi, A., Akash, B., Abu-Nada, E., Nijmeh, S. and Al-Hinti, I. (2008) Prospects of Geothermal Energy Utilization in Jordan. Energy Sources, Part A: Recovery, Utilization, and Environmental Effects, 30, 1619-1627. https://doi.org/10.1080/15567030701436388

[14] International Geothermal Association (IGA) (2018) Geothermal Power Database. https://www.geothermal-energy.org/explore/our-databases/geothermal-power-data base/

[15] Hrayshat, E.S. (2009) Status and Outlook of Geothermal Energy in Jordan. Energy for Sustainable Development, 13, 124-128. https://doi.org/10.1016/j.esd.2009.05.004

[16] Van Nguyen, M., Arason, S., Gissurarson, M. and Pálsson, P.G. (2015) Uses of Geothermal Energy in Food and Agriculture-Opportunities for Developing Countries. FAO. Rome.

[17] Lund, J.W., Freeston, D.H. and Boyd, T.L. (2011) Direct Utilization of Geothermal Energy 2010 Worldwide Review. Geothermics, 40, 159-180.

https://doi.org/10.1016/j.geothermics.2011.07.004

[18] Mburu, M. (2009) Geothermal Energy Utilization. Short Course IV on Exploration 
for Geothermal Resources, UNU-GTP, GDC and KenGen, Lake Naivasha, Kenya, 27 October-18 November 2012, 22 p.

[19] Sunna, B. (2015) Occurrences and Possible Applications of Geothermal Energy in Jordan. International Conference on Geology, FL, 22-23 June 2015.

[20] Al-Khasawneh, Y., Albatayneh, A. and Althawabiah, S. (2019) The Application of Ground-Source Heat Pumps for a Residential Building in Jordan. In: Alalouch, C., Abdalla, H., Bozonnet, E., Elvin, G. and Carracedo, O., Eds., Advanced Studies in Energy Efficiency and Built Environment for Developing Countries. Advances in Science, Technology \& Innovation (IEREK Interdisciplinary Series for Sustainable Development), Springer, Cham, 161-167. https://doi.org/10.1007/978-3-030-10856-4_16

[21] Al Dhoun, H. and Al-Zyoud, S. (2019) Geochemical Assessments and Potential Energy Sources Evaluations Based on Oil Shale and Geothermal Resource in Wadi Al-Shallala-North Jordan. International Journal of Geosciences, 10, 351-365. https://doi.org/10.4236/ijg.2019.103020

[22] Al-Dabbas, M. (2011) Achievement of Geothermal Energy Using Ground Heat Exchanger in Ma'en. Journal of Mechanical Science and Technology, 25, 2013-2023. https://doi.org/10.1007/s12206-011-0520-y

[23] Abu Raed, A.S. and Sakhrieh, A.H. (2013) Energy Saving by the Means of Geothermal Energy. Journal of Clean Energy Technologies, 1, 243-245.

[24] Saudi, A. and Swarieh, A. (2015) Geothermal Energy Resources in Jordan, Country Update Paper. Proceedings of 2015 World Geothermal Congress, 19-25 April 2015.

[25] Myslil, V. (1988) Report on Evaluation of Geothermal Potential of Jordan. Strojexport prague, Gzechoslovakia, Geological Survey, Prague.

[26] Williams, H., Ramini, H. and Alzyoud, M. (1990) Regional Petroleum Geochemistry of Jordan. Amman, Natural Rescources Authority, 66 p.

[27] Ozgener, O. and Kocer, G. (2004) Geothermal Heating Application. Energy Sources, 26, 353-360. https://doi.org/10.1080/00908310490424105

[28] Ministry of Water and Irrigation (MWI) (2019) Jordan Water Sector-Facts and Figures 2017. http://www.waj.gov.jo/sites/en-us/default.aspx

[29] Department of Statics (DoS) (2019) Estimated Population of the Kingdom by Governorate, Locality, Sex and Household. http://dosweb.dos.gov.jo/population/population-2/

[30] Shariah, A., Tashtoush, B. and Rousan, A. (1997) Cooling and Heating Loads in Residential Buildings in Jordan. Energy and Buildings, 26, 137-143. https://doi.org/10.1016/S0378-7788(96)01027-4

[31] Sanner, B. (2001) Shallow Geothermal Energy. GHC Bulletin.

[32] Akash, B., Abu-Nada, E., Al-Sarkhi, A., Shishan, A., Ibrahim, A. and Nijmeh, S. (2006) Three-Dimensional Simulation of a Standing Column Well for Potential Applications in Jordan. Global Conference on Renewable Energy Approaches in Desert Regions, British Geological SurveylJordan Natural Resources Authority Internal Joint Report. Amman, Jordan.

[33] Popovski, K. and Vasilevska, S.P. (2003) Heating Greenhouses with Geothermal Energy. Proceedings of the International Geothermal Workshop, Sochi, Russian Federation, 6-10 October 2003, 17 p.

[34] Mahmoudi, H., Spahis, N., Goosen, M.F., Ghaffour, N., Drouiche, N. and Ouagued, A. (2010) Application of Geothermal Energy for Heating and Freshwater Production in a Brackish Water Greenhouse Desalination Unit: A Case Study from Algeria. 
Renewable and Sustainable Energy Reviews, 14, 512-517.

https://doi.org/10.1016/j.rser.2009.07.038

[35] Boyd, T.L. and Lund, J.W. (2003) Geothermal Heating of Greenhouses and Aquaculture Facilities. Proceedings of the International Geothermal Conference, Reykjavik, 14-17 September 2003, 14-19. 